\title{
Do Statin Medications Improve Periodontal Health and/or Outcomes? A Systematic Review
}

\author{
Eboné Jordan, ${ }^{\star}$ Yung-Ting Hsu, ${ }^{*}$ and Jill Bashutski*
}

\section{Focused Clinical Question:}

For adult patients (aged $\geq 30$ years) with chronic periodontitis, does the use of 3-hydroxy-3-methyl-glutaryl coenzyme A reductase inhibitors (statins) improve periodontal health?

\section{Clinical Scenario:}

A 59-year-old female with a history of hyperlipidemia presents for periodontal maintenance care. She has been taking a statin medication for 4 years, during which time she received comprehensive periodontal therapy, including regenerative surgery in two quadrants. Post-surgical evaluation revealed substantial gains in clinical attachment and probing depth reduction. Radiographically, significant fill of the intrabony defect was observed. Before treatment, she was very anxious about losing more teeth and is now curious about the stability of her periodontal treatment. For clinical and radiographic presentation of the patient, see Figures 1 and 2.

Clin Adv Periodontics 2014;4:194-202.

Key Words: Adult; chronic periodontitis; hydroxymethylglutaryl-CoA reductase inhibitors, therapeutic use; hyperlipidemia; treatment outcome.

\section{Background}

Chronic periodontitis $(\mathrm{CP})$ is an inflammatory disease induced by the presence of bacterial pathogens and their byproducts. The observed tissue and bone breakdown results from a long-standing inflammatory response mounted by the immune system of the host. ${ }^{1}$ Traditionally, treatment of CP has focused on both non-surgical and surgical removal of bacterial plaque and calculus by mechanical means, with the aim to reduce the amount of local factors that trigger the immune response. More recently, the approach has shifted from a focus solely on controlling the exogenous bacterial factors to the goal of controlling the responses of the host to these triggers and encouraging regeneration of tissue-in other words, host modulation. $^{2}$

Manipulation of the proinflammatory state with pharmacologic therapies has been investigated. ${ }^{2,3}$ Many of the substances (i.e., non-steroidal anti-inflammatory drugs, statins, bisphosphonates) used are commonly prescribed drugs that periodontal patients are already taking as a part of a concurrent systemic disease treatment. ${ }^{2}$ Examples of such substances are the 3-hydroxy-3-methyl-glutaryl coenzyme A (HMG-CoA) reductase inhibitors, commonly known as statins. These drugs act as competitive inhibitors of the

\footnotetext{
* Department of Periodontics and Oral Medicine, School of Dentistry, University of Michigan, Ann Arbor, MI.
}

Submitted October 16, 2013; accepted for publication February 11, 2014

doi: 10.1902/cap.2014.130084 enzyme HMG-CoA reductase, thereby preventing a crucial step in cholesterol synthesis in the liver. ${ }^{4}$ This effectively lowers cholesterol and secondarily decreases the incidence of cardiovascular disease. ${ }^{4}$

Because inflammation plays a role in cardiovascular disease, the anti-inflammatory properties of statins have been studied previously. ${ }^{5}$ In addition to their cholesterol-lowering effects, they have pleiotropic features, such as inhibiting the release of proinflammatory mediators, specifically cytokines (i.e., tumor necrosis factor- $\alpha$, chemokines, interleukin [IL] family) and matrix metalloproteinases (MMPs). ${ }^{6}$ MMPs have long been associated with collagen and extracellular matrix degradation in periodontal disease. There are four categories of MMPs - collagenases, gelatinases, stromelysins, and membrane type-with collagenases (MMP-1, MMP-8, MMP-13) and gelatinases (MMP-2, MMP-9) being most often implicated in periodontitis. ${ }^{7,8}$ Statins have been shown to reduce the expression of lipopolysaccharide (LPS)-induced MMP-1, MMP-8, and MMP-9 in monocytes ${ }^{9}$ and reduce the expression of MMP-9 in osteoblastic cells. ${ }^{10}$ LPS is a well-known component of the cell membrane of Gramnegative bacteria, which are also the predominant type of microorganism found in periodontal disease. ${ }^{11}$ Animal studies demonstrated the effect of statins on alveolar bone loss and gingival inflammation. In a ligature-induced periodontitis model in rats, oral simvastatin (SMV) administration reduced alveolar bone loss and decreased the levels of the proinflammatory cytokines MMP-1 and MMP-8, as well as receptor activator of nuclear factor- $\mathrm{KB}$ (RANK) and RANK ligand. ${ }^{12}$ In another animal study, both alveolar bone loss 


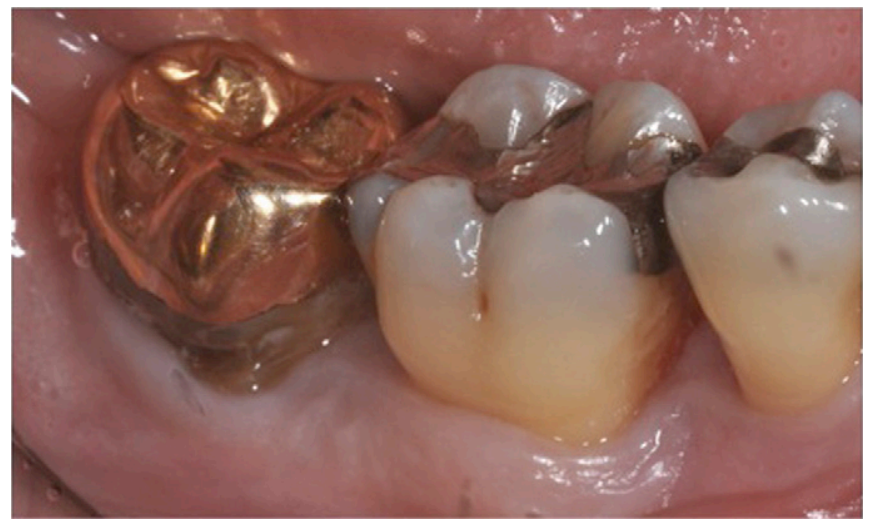

FIGURE 1 Initial clinical presentation.
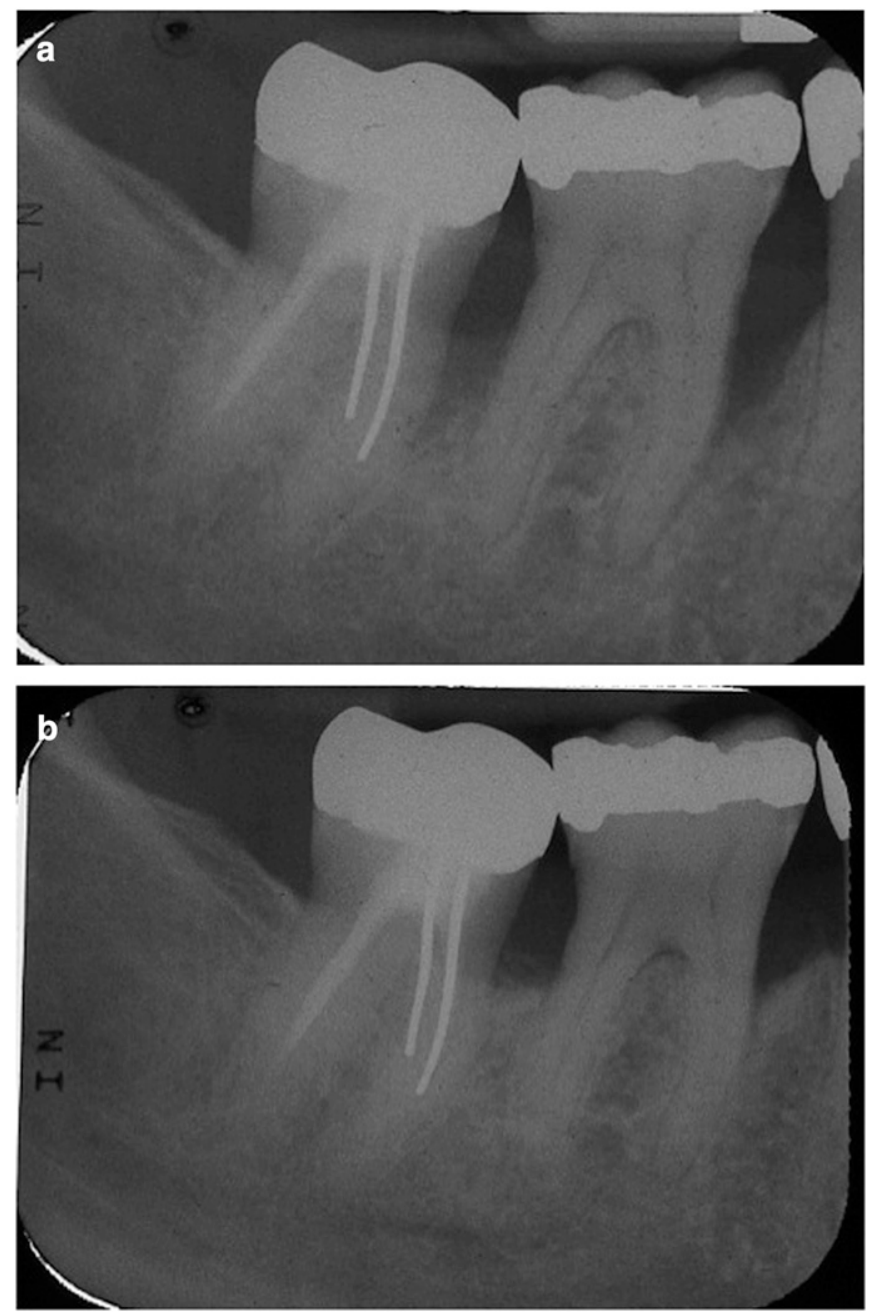

FIGURE 2a Lower right quadrant before comprehensive periodontal treatment with concurrent systemic statin administration. $2 \mathrm{~b}$ Lower right quadrant 2 years after comprehensive periodontal treatment with concurrent systemic statin administration.

and osteoclastogenesis were significantly reduced when SMV was administered to rats with LPS-induced periodontitis. ${ }^{13}$ These findings in animal studies support previously published evidence on the effect of statins on improved bone mineral density and bone formation with statin use in humans. ${ }^{14}$ Accordingly, there is biologic plausibility that the anti-inflammatory and bone formation-promoting actions of statins could positively affect periodontal treatment outcomes in humans.

Statins are among the most prescribed and top-selling drugs in the United States each year. ${ }^{15}$ This is especially true among middle-aged adults, in whom systemic diseases, such as hyperlipidemia, atherosclerosis, and other cardiovascular diseases, tend to be most common. $\mathrm{CP}$, too, has a higher prevalence among adults aged $\geq 30$ years. ${ }^{16}$ Because age is a risk indicator for both atherosclerosis and $\mathrm{CP}$, use of statin therapy could be a potentially convenient and cost-effective strategy to address both chronic diseases simultaneously.

Although statins have potentially dangerous adverse effects, including elevated liver enzymes and rhabdomyolysis, their incidence is relatively rare. ${ }^{17}$ This makes the drug an ideal choice for concomitant therapeutic use for periodontal disease. With the above purported actions of statins in inflammation, it is biologically plausible to expect beneficial effects of statins in patients with CP. The aim of this review is to examine the effects of statins, used both systemically and locally, on treatment outcomes for CP.

\section{Search Strategy}

A literature search of PubMed and the Cochrane Database was performed using the following MeSH terms: (("periodontal diseases"[MeSH Terms] OR ("periodontal"[All Fields] AND "diseases"[All Fields]) OR "periodontal diseases"[All Fields] OR ("periodontal"[All Fields] AND "disease"[All Fields]) OR "periodontal disease"[All Fields]) AND ("hydroxymethylglutaryl-coa reductase inhibitors"[Pharmacological Action] OR "hydroxymethylglutaryl-coa reductase inhibitors"[MeSH Terms] OR ("hydroxymethylglutaryl-coa"[All Fields] AND "reductase"[All Fields] AND "inhibitors"[All Fields]) OR "hydroxymethylglutaryl-coa reductase inhibitors"[All Fields] OR “statins”[All Fields])) AND ("1980"[PDAT]: “3,000”[PDAT])

\section{Search Outcome}

The literature search yielded 49 papers related to the search topic. Forty-six full-text articles were reviewed. Three papers were written in languages other than English. Of the 46 reviewed papers, four randomized clinical trials $(\mathrm{RCTs})^{18-21}$ and seven cross-sectional or cohort studies ${ }^{22-28}$ were selected for inclusion (Tables 1 and 2). The remaining papers were eliminated because of lack of human participants or lack of direct evaluation of periodontal conditions.

\section{Discussion}

This review of the literature revealed a paucity of clinically controlled trials and a noticeable heterogeneity in design among cross-sectional and cohort studies regarding the 


\section{TABLE 1 RCTs}

\begin{tabular}{|c|c|c|c|c|c|}
\hline Reference & Patient Group & $\begin{array}{l}\text { Study Type } \\
\text { (Level of } \\
\text { Evidence) }\end{array}$ & Methods & Key Results & Comments \\
\hline
\end{tabular}

association of HMG-CoA reductase inhibitors and periodontal disease. For the clinical trials, statin use, both systemically and locally, was associated with an improvement in periodontal parameters. ${ }^{18-20}$ One of the trials ${ }^{18}$ showed a statistically significant improvement on tooth mobility and radiographic bone level with the once-daily use of systemically administered atorvastatin (ATV). However, these results should be interpreted with caution because of the short follow-up period ( 3 months) and atypical method of assessing tooth mobility. Conversely, the radiographic bone level can be seen as statistically and, presumably, clinically significant, with the control group losing bone height (crest of alveolar bone-cemento-enamel junction [CAB$\mathrm{CEJ]}$ at baseline [BL], $2.71 \pm 1.43 \mathrm{~mm}$ versus 3 months, $2.80 \pm 1.52 \mathrm{~mm}$ ) and the test (ATV) group gaining bone height (CAB-CEJ at BL, $2.85 \pm 1.50 \mathrm{~mm}$ versus 3 months, 
TABLE 1 (Continued) RCTs

\begin{tabular}{|c|c|c|c|c|c|}
\hline Reference & Patient Group & $\begin{array}{l}\text { Study Type } \\
\text { (Level of } \\
\text { Evidence) }\end{array}$ & Methods & Key Results & Comments \\
\hline
\end{tabular}

$\mathrm{PI}=$ plaque index; $\mathrm{GR}=$ gingival recession; $\mathrm{SRP}=$ scaling and root planing; $\mathrm{OHI}=$ oral hygiene instruction; $\mathrm{LDL}=$ low-density lipoprotein; IBD $=$ intrabony defect; FDG/PET-CT $=$ 2-18F-fluoro-2-deoxy-D-glucose/positron emission tomography-computed tomography.

$2.10 \pm 1.14 \mathrm{~mm})$. The most significant improvement in common periodontal parameters was seen with the use of a locally delivered form of SMV, used as an adjunct to non-surgical periodontal therapy. ${ }^{19,20}$ Probing depth (PD), clinical attachment level (CAL), and inflammation (as measured by a modified sulcus bleeding index [mSBI]) all exhibited statistically and, presumably, clinically significant improvement over controls for both a systemically healthy ${ }^{19}$ and a diabetic ${ }^{20}$ participant group; on average, more than twice the reduction in PD and CAL was seen in the SMV group (for both studies) when compared with the placebo group for all time points studied. ${ }^{19,20}$ Therapeutic treatment outcomes may be improved when administering a statin locally compared with systemically. The application of a statin on a localized level may eliminate the resultant dose decrease seen at bone sites after the first-pass liver metabolism. ${ }^{29}$ Furthermore, in two of the above trials, ${ }^{19,20}$ gingival crevicular fluid (GCF) analysis of the treatment site demonstrated that the delivery vehicle allowed for an extended release of the drug for up to 30 days.

With regard to the cross-sectional and cohort studies, there was only a weak positive correlation of statins to improved periodontal parameters. Many of the studies showed an association with statin use and fewer periodontal pockets (defined as PDs of 3 to $4 \mathrm{~mm}$ ). ${ }^{24,25,27}$ Parameters such as $\mathrm{PD}, \mathrm{CAL}$, and bleeding on probing (BOP) can serve as surrogate endpoints for the actual true endpoint of tooth loss. Interestingly, however, the retrospective studies evaluating the impact of statin therapy on tooth loss showed either no reduction in tooth $\operatorname{loss}^{23}$ or weak association with tooth loss reduction ${ }^{22}$-one in which a reduction in tooth loss was related to time of periodontal disease diagnosis and time of statin medication being dispensed. For the study that did show a slight reduction in tooth loss, ${ }^{22}$ it was interesting to note that this relationship was not found to be dose dependent. One must regard the results of this retrospective cohort study, in which only insurance information was evaluated, with caution. Although the authors tried to control for the potential confounding factor of extractions attributable to non-periodontally related issues (i.e., consideration of total caries-related procedures), the lack of information regarding the reason for extraction does not permit a true understanding of periodontal tooth loss in statin users, because non-users may have had similar tooth loss rates that were unrelated to periodontal disease. Additionally, studies suggest that well-maintained, compliant patient populations may exhibit higher rates of tooth loss than poorly maintained populations-a trend that may provide insight into the lack of difference seen between the statin group and others.

Statins exert their inflammation-modulating effects on many levels, including the reduction of C-reactive protein levels, ${ }^{30}$ blockage of the effects of proinflammatory cytokine IL-6, ${ }^{31}$ and suppression of tissue-degradative MMPs. ${ }^{9}$ Animal studies demonstrated the positive effects of statins on bone metabolism, specifically with regard to stimulation of bone morphogenetic protein- $2^{32}$ and increased expression of vascular endothelial growth factor in osteoblasts. ${ }^{33}$ Seto et al. ${ }^{34}$ showed increased bone formation in rat calvaria after the topical administration of SMV, revealing its ability to maintain high osteoblastic function. In addition, it was demonstrated in another animal study that the application of $\mathrm{SMV}$, in a cyclosporine $\mathrm{A}$ (CsA)-induced periodontal disease model, counteracted the deleterious effects of the CsA on bone turnover. ${ }^{35}$ 
TABLE 2 Human Cross-Sectional and Cohort Studies

\begin{tabular}{|c|c|c|c|c|c|}
\hline Reference & Patient Group & $\begin{array}{l}\text { Study Type } \\
\text { (Level of } \\
\text { Evidence) }\end{array}$ & Methods & Key Results & Comments \\
\hline $\begin{array}{c}\text { Saver et al., } \\
2007^{23}\end{array}$ & $\begin{array}{l}\mathrm{N}=12,631 \mathrm{HM} 0 \text { patients, } \\
\text { aged } 48 \text { to } 62 \text { years at } \\
\text { the end of the study } \\
\text { period who had been } \\
\text { diagnosed with CP by } \\
\text { a general dentist or } \\
\text { periodontist in the last } \\
3 \text { years of the study } \\
\text { period; } \\
\text { Mild CP: bone loss } \leq 30 \% \\
\text { of the tooth root, clinical } \\
\text { AL, PD of } 4 \text { to } 6 \mathrm{~mm} \text {, or } \\
\text { grade I furcation } \\
\text { involvement; } \\
\text { Moderate CP: bone loss } \\
30 \% \text { to } 50 \% \text { of the } \\
\text { tooth root, AL, PD of } \\
5 \text { to } 7 \mathrm{~mm}, \text { and } \\
\text { furcation involvement } \\
\text { less than grade I; } \\
\text { Severe CP: bone } \\
\text { loss } \geq 50 \% \text { of the } \\
\text { tooth root, possible } \\
\text { immediate tooth } \\
\text { loss, and PD } \geq 7 \mathrm{~mm}\end{array}$ & $\begin{array}{l}\text { Retrospective } \\
\text { cohort }\end{array}$ & $\begin{array}{l}\text { Analyzed statin prescription } \\
\text { patterns over a } 7 \text {-year } \\
\text { evaluation period (1996 } \\
\text { to 2002) and related them } \\
\text { to dental extractions. }\end{array}$ & $\begin{array}{l}\text { Unadjusted results } \\
\text { showed increased } \\
\text { tooth loss for statin } \\
\text { users. } \\
\text { After adjusting for smoking } \\
\text { and diabetes, statin use } \\
\text { showed no effect on } \\
\text { tooth loss (increased or } \\
\text { decreased). } \\
\text { Statin use did not show } \\
\text { benefits for mild versus } \\
\text { severe disease, nor for } \\
\text { non-smokers versus } \\
\text { former smokers versus } \\
\text { current smokers. }\end{array}$ & $\begin{array}{l}\text { Unable to see the } \\
\text { effects of statins } \\
\text { on clinical } \\
\text { parameters } \\
\text { (CAL, } \\
\text { PD, BOP). } \\
\text { Ultimately, tooth } \\
\text { loss is the } \\
\text { endpoint, but } \\
\text { investigators } \\
\text { were unable to } \\
\text { provide specific } \\
\text { information on } \\
\text { the reason for } \\
\text { tooth loss; } \\
\text { however, the } \\
\text { large sample } \\
\text { size may negate } \\
\text { potential } \\
\text { variations. }\end{array}$ \\
\hline
\end{tabular}

Based on the results presented herein, there is promising, albeit preliminary, information regarding the benefits of statin use on periodontal treatment outcomes. The current widespread use of these medications in the adult population coupled with the increased prevalence of periodontal disease in this same population makes their use in periodontal therapy both practical and economical. The early evidence of the prospective RCTs are promising, especially given the benefit of a locally delivered method of administration that is associated with fewer side effects and a reduced need for patient compliance. However, the conclusions are a reflection of a relatively small sample size and therefore need to be demonstrated in the larger population as a whole. Therefore, future endeavors might include large-scale, crosssectional studies that correlate statin use with overall periodontal condition (i.e., National Health and Nutrition Examination Survey III data mining); such an analysis would provide a large enough sample size to control for confounders. With that correlation established, research should then be aimed at evaluating the benefit of HMGCoA reductase inhibitors on periodontal disease through well-controlled, largely powered, prospective clinical trials 
TABLE 2 (Continued) Human Cross-Sectional and Cohort Studies

\begin{tabular}{|c|c|c|c|c|c|}
\hline Reference & Patient Group & $\begin{array}{l}\text { Study Type } \\
\text { (Level of } \\
\text { Evidence) }\end{array}$ & Methods & Key Results & Comments \\
\hline $\begin{array}{l}\text { Saxlin et al., } \\
2009^{25}\end{array}$ & $\begin{array}{l}\mathrm{N}=2,032 \text { non-smoking } \\
\text { dentate adults aged } \\
40 \text { to } 69 \text { years without } \\
\text { diabetes or rheumatoid } \\
\text { diseases }\end{array}$ & Cross-sectional & $\begin{array}{l}\text { Calibrated examiners } \\
\text { performed periodontal } \\
\text { evaluations using PD } \\
\text { (4 sites per tooth) } \\
\text { measurements to diagnose } \\
\text { disease; disease } \\
\text { status based on } \\
\text { "deepened" pockets } \\
\text { ( } \geq 4 \mathrm{~mm}) \text { or "deep" } \\
\text { pockets }(\geq 6 \mathrm{~mm}) ; \\
\text { also evaluated BOP. } \\
\text { Statin information } \\
\text { garnered from health } \\
\text { questionnaire. }\end{array}$ & $\begin{array}{l}\text { One hundred thirty-four } \\
\text { patients used statins. } \\
\text { Among the total study } \\
\text { population, statins } \\
\text { showed a weak } \\
\text { negative association } \\
\text { with deepened ( } \geq 4 \mathrm{~mm} \text { ) } \\
\text { pockets and with deep } \\
\text { ( } \geq 6 \mathrm{~mm} \text { ) pockets } \\
\text { showing slightly stronger } \\
\text { negative association, } \\
\text { but not to the point of } \\
\text { statistical significance. }\end{array}$ & $\begin{array}{l}\text { Statin medication } \\
\text { was weakly } \\
\text { negatively } \\
\text { associated } \\
\text { with the } \\
\text { presence and } \\
\text { severity of } \\
\text { periodontal } \\
\text { infection; } \\
\text { this was } \\
\text { seen in patients } \\
\text { with plaque and } \\
\text { increased BOP; } \\
\text { in patients } \\
\text { without plaque } \\
\text { or BOP, there } \\
\text { was a slight } \\
\text { increase in the } \\
\text { likelihood of } \\
\text { deepened } \\
\text { periodontal } \\
\text { pockets with } \\
\text { statin } \\
\text { medication. } \\
\text { Statin medication } \\
\text { appears to have } \\
\text { an effect on the } \\
\text { periodontium } \\
\text { and may be } \\
\text { dependent } \\
\text { on the } \\
\text { inflammatory } \\
\text { state of the } \\
\text { tissues. }\end{array}$ \\
\hline
\end{tabular}


TABLE 2 (Continued) Human Cross-Sectional and Cohort Studies

\begin{tabular}{|c|c|c|c|c|c|}
\hline Reference & Patient Group & $\begin{array}{l}\text { Study Type } \\
\text { (Level of } \\
\text { Evidence) }\end{array}$ & Methods & Key Results & Comments \\
\hline $\begin{array}{c}\text { Sangwan } \\
\text { et al., } \\
2013^{27}\end{array}$ & $\begin{array}{l}\mathrm{N}=140 \text { adults } \\
\text { with } \geq 16 \text { teeth: } 94 \\
\text { patients with } \\
\text { hyperlipidemia } \\
\text { (50 statin users, } \\
44 \text { non-pharmacologic } \\
\text { therapy); } 46 \\
\text { normolipidemic } \\
\text { patients as controls }\end{array}$ & Cross-sectional & $\begin{array}{l}\text { Clinical examination included } \\
\text { PI, Gl, PD, and CAL. } \\
\text { Biochemical measures } \\
\text { included total cholesterol, } \\
\text { HDL, LDL, and serum } \\
\text { triglyceride. }\end{array}$ & $\begin{array}{l}\text { The periodontal status of } \\
\text { statin users did not differ } \\
\text { significantly from normal } \\
\text { lipid level patients. } \\
\text { There was significantly higher } \\
\text { PI and Gl in hyperlipidemic } \\
\text { statin non-users than statin } \\
\text { users and normolipidemic } \\
\text { patients. } \\
\text { Mean PD values were } \\
\text { statistically significantly } \\
\text { higher in the hyperlipidemic } \\
\text { non-statin users than } \\
\text { the control group or } \\
\text { hyperlipidemic statin users. } \\
\text { PD and GI were significantly } \\
\text { higher in the hyperlipidemic } \\
\text { non-statin user group } \\
\text { compared with the } \\
\text { normolipidemic group } \\
\text { and statin user group. }\end{array}$ & $\begin{array}{l}\text { This study } \\
\text { evaluated } \\
\text { patients divided } \\
\text { according to } \\
\text { lipid levels, } \\
\text { enabling an } \\
\text { assessment of } \\
\text { the relationship } \\
\text { of lipid levels } \\
\text { to periodontitis } \\
\text { and the potential } \\
\text { modification by } \\
\text { statin use. }\end{array}$ \\
\hline $\begin{array}{l}\text { Suresh } \\
\text { et al., } \\
2013^{28}\end{array}$ & $\begin{array}{l}\mathrm{N}=30 \text { adults aged } \\
40 \text { to } 60 \text { years with } \\
\text { generalized CP (AL of } \\
3 \text { to } 5 \mathrm{~mm} \text { in }>30 \% \\
\text { of sites); group } 1 \\
\text { ( } \mathrm{n}=15), 20 \mathrm{mg} / \mathrm{d} \\
\text { ATV; group } 2(\mathrm{n}=15) \text {, } \\
\text { control }\end{array}$ & Cross-sectional & $\begin{array}{l}\text { The clinical parameters } \\
\text { recorded were PI, GI, } \\
\text { and CAL. } \\
\text { GCF samples analyzed for } \\
\text { IL- } 1 \beta \text { using commercially } \\
\text { available ELISA. }\end{array}$ & $\begin{array}{l}\text { There was no difference in } \\
\text { clinical parameters } \\
\text { between those taking } \\
\text { statins and control } \\
\text { patients. } \\
\text { GCF IL-1 } \beta \text { levels in } \\
\text { patients with CP } \\
\text { on statin medication } \\
\text { were lower than patients } \\
\text { with CP not taking statin } \\
\text { medication. }\end{array}$ & $\begin{array}{l}\text { This study does not } \\
\text { assess PDs or } \\
\text { measurements } \\
\text { of bone levels } \\
\text { (i.e., radiographic } \\
\text { assessment). } \\
\text { The patients in this } \\
\text { study were only } \\
\text { taking statin } \\
\text { medication for } \\
6 \text { months, which } \\
\text { may have } \\
\text { prevented the } \\
\text { ability to detect } \\
\text { differences in } \\
\text { clinical } \\
\text { parameters. }\end{array}$ \\
\hline
\end{tabular}

$\mathrm{HMO}=$ health maintenance organization; $\mathrm{AL}=$ attachment loss; $\mathrm{PI}=$ plaque index; $\mathrm{PIBI}=$ periodontal inflammatory burden index; $\mathrm{LDL}=$ low-density lipoprotein; $\mathrm{HDL}=$ high-density lipoprotein; $\mathrm{Gl}=$ gingival index; ELISA = enzyme-linked immunosorbent assay. 
that showcase the improvement in clinical parameters in patients with periodontal disease.

\section{Clinical Bottom Line}

In adult patients (aged $\geq 30$ years) with CP, the use of statins may show a positive effect on periodontal status (i.e., tooth loss, inflammation). Additionally, in patients undergoing non-surgical periodontal therapy, concomitant administration of statins may help improve periodontal outcomes.

\section{Acknowledgments}

Dr. Bashutski has been paid as an advisor and received consulting fees from Delta Dental (San Francisco, California), Eli Lilly (Indianapolis, Indiana), and the Osteology Foundation (Lucerne, Switzerland). Drs. Jordan and Hsu report no conflicts of interest related to this study.

\section{CORRESPONDENCE:}

Dr. Jill Bashutski, 1011 N. University Ave., Ann Arbor, MI 48109-1078. E-mail: jillbash@umich.edu. 


\section{References}

1. Kornman KS, Page RC, Tonetti MS. The host response to the microbial challenge in periodontitis: Assembling the players. Periodontol 2000 1997;14:33-53.

2. Salvi GE, Lang NP. Host response modulation in the management of periodontal diseases. J Clin Periodontol 2005;32(Suppl. 6):108-129.

3. El-Sharkawy H, Aboelsaad N, Eliwa M, et al. Adjunctive treatment of chronic periodontitis with daily dietary supplementation with omega-3 fatty acids and low-dose aspirin. J Periodontol 2010;81:1635-1643.

4. Istvan ES, Deisenhofer J. Structural mechanism for statin inhibition of HMG-CoA reductase. Science 2001;292:1160-1164.

5. Endres M. Statins: Potential new indications in inflammatory conditions. Atheroscler Suppl 2006;7:31-35.

6. Forrester JS, Libby P. The inflammation hypothesis and its potential relevance to statin therapy. Am J Cardiol 2007;99:732-738.

7. Sodek J, Overall CM. Matrix metalloproteinases in periodontal tissue remodelling. Matrix Suppl 1992;1(Suppl.):352-362.

8. Ingman T, Sorsa T, Lindy O, Koski H, Konttinen YT. Multiple forms of gelatinases/type IV collagenases in saliva and gingival crevicular fluid of periodontitis patients. J Clin Periodontol 1994;21:26-31.

9. Sundararaj KP, Samuvel DJ, Li Y, et al. Simvastatin suppresses LPS-induced MMP-1 expression in U937 mononuclear cells by inhibiting protein isoprenylation-mediated ERK activation. J Leukoc Biol 2008;84:1120-1129.

10. Thunyakitpisal PD, Chaisuparat R. Simvastatin, an HMG-CoA reductase inhibitor, reduced the expression of matrix metalloproteinase- 9 (Gelatinase B) in osteoblastic cells and HT1080 fibrosarcoma cells. J Pharmacol Sci 2004;94:403-409.

11. Socransky SS, Haffajee AD, Cugini MA, Smith C, Kent RL Jr. Microbial complexes in subgingival plaque. J Clin Periodontol 1998;25:134-144.

12. Dalcico R, de Menezes AM, Deocleciano OB, et al. Protective mechanisms of simvastatin in experimental periodontal disease. $J$ Periodontol 2013;84:1145-1157.

13. Jin J, Zhang X, Lu Z, et al. Simvastatin inhibits lipopolysaccharideinduced osteoclastogenesis and reduces alveolar bone loss in experimental periodontal disease [published online ahead of print October 7, 2013]. J Periodontal Res doi:10.1111/jre.12132.

14. Chuengsamarn S, Rattanamongkoulgul S, Suwanwalaikorn S, Wattanasirichaigoon S, Kaufman L. Effects of statins vs. non-statin lipid-lowering therapy on bone formation and bone mineral density biomarkers in patients with hyperlipidemia. Bone 2010;46:1011-1015.

15. Ogbru O. Top 10 drugs prescribed in the U.S. Available at: http://www. onhealth.com/top_drugs_prescribed_in_the_us/views.htm. Accessed on December 12, 2013.

16. Eke PI, Dye BA, Wei L, Thornton-Evans GO, Genco RJ; CDC Periodontal Disease Surveillance Workgroup. Prevalence of periodontitis in adults in the United States: 2009 and 2010. J Dent Res 2012;91:914-920.

17. Silva MA, Swanson AC, Gandhi PJ, Tataronis GR. Statin-related adverse events: A meta-analysis. Clin Ther 2006;28:26-35.

18. Fajardo ME, Rocha ML, Sánchez-Marin FJ, Espinosa-Chávez EJ. Effect of atorvastatin on chronic periodontitis: A randomized pilot study. J Clin Periodontol 2010;37:1016-1022.

19. Pradeep AR, Thorat MS. Clinical effect of subgingivally delivered simvastatin in the treatment of patients with chronic periodontitis: A randomized clinical trial. J Periodontol 2010;81:214-222.

20. Pradeep AR, Rao NS, Bajaj P, Kumari M. Efficacy of subgingivally delivered simvastatin in the treatment of patients with type 2 diabetes and chronic periodontitis: A randomized double-masked controlled clinical trial. J Periodontol 2013;84:24-31.

21. Subramanian S, Emami H, Vucic E, et al. High-dose atorvastatin reduces periodontal inflammation: A novel pleiotropic effect of statins. $J \mathrm{Am}$ Coll Cardiol 2013;62:2382-2391.

22. Cunha-Cruz J, Saver B, Maupome G, Hujoel PP. Statin use and tooth loss in chronic periodontitis patients. J Periodontol 2006;77:1061-1066.

23. Saver BG, Hujoel PP, Cunha-Cruz J, Maupomé G. Are statins associated with decreased tooth loss in chronic periodontitis? J Clin Periodontol 2007;34:214-219.

24. Lindy O, Suomalainen K, Mäkelä M, Lindy S. Statin use is associated with fewer periodontal lesions: A retrospective study. BMC Oral Health 2008;8:16-22.

25. Saxlin T, Suominen-Taipale L, Knuuttila M, Alha P, Ylöstalo P. Dual effect of statin medication on the periodontium. J Clin Periodontol 2009; 36:997-1003.

26. Meisel P, Kohlmann T, Wallaschofski H, Kroemer HK, Kocher T. Cholesterol, C-reactive protein, and periodontitis: HMG-CoA-reductase inhibitors (statins) as effect modifiers. ISRN Dent 2011;2011: 125168 .

27. Sangwan A, Tewari S, Singh H, Sharma RK, Narula SC. Periodontal status and hyperlipidemia: Statin users versus non-users. J Periodontol 2013;84:3-12.

28. Suresh S, Narayana S, Jayakumar P, Sudhakar U, Pramod V. Evaluation of anti-inflammatory effect of statins in chronic periodontitis. Indian J Pharmacol 2013;45:391-394.

29. Vaziri H, Naserhoijati-Roodsari R, Tahsili-Fahadan N, et al. Effect of simvastatin administration on periodontitis-associated bone loss in ovariectomized rats. J Periodontol 2007;78:1561-1567.

30. Strandberg TE, Vanhanen H, Tikkanen MJ. Effect of statins on Creactive protein in patients with coronary artery disease. Lancet 1999; 353:118-119.

31. Jougasaki M, Ichiki T, Takenoshita Y, Setoguchi M. Statins suppress interleukin-6-induced monocyte chemo-attractant protein-1 by inhibiting Janus kinase/signal transducers and activators of transcription pathways in human vascular endothelial cells. Br J Pharmacol 2010; 159:1294-1303.

32. Mundy G, Garrett R, Harris S, et al. Stimulation of bone formation in vitro and in rodents by statins. Science 1999;286:1946-1949.

33. Maeda T, Kawane T, Horiuchi N. Statins augment vascular endothelial growth factor expression in osteoblastic cells via inhibition of protein prenylation. Endocrinology 2003;144:681-692.

34. Seto H, Ohba H, Tokunaga K, Hama H, Horibe M, Nagata T. Topical administration of simvastatin recovers alveolar bone loss in rats. J Periodontal Res 2008;43:261-267.

35. Nassar PO, Nassar CA, Guimarães MR, et al. Simvastatin therapy in cyclosporine A-induced alveolar bone loss in rats. J Periodontal Res $2009 ; 44: 479-488$.

36. Löe H, Silness J. Periodontal disease in pregnancy. I. Prevalence and severity. Acta Odontol Scand 1963;21:533-551.

37. Silness J, Löe H. Periodontal disease in pregnancy. II. Correlation between oral hygiene and periodontal condition. Acta Odontol Scand 1964;22:121-135.

38. Laster L, Laudenbach KW, Stoller NH. An evaluation of clinical tooth mobility measurements. J Periodontol 1975;46:603-607.

39. Hujoel PP, Leroux BG, Selipsky H, White BA. Non-surgical periodontal therapy and tooth loss. A cohort study. J Periodontol 2000;71:736-742. 